\title{
Effects of temperature and ocean acidification on shell characteristics of Argopecten purpuratus: implications for scallop aquaculture in an upwelling-influenced area
}

\author{
Nelson A. Lagos ${ }^{1, *}$, Samanta Benítez ${ }^{1}$, Cristian Duarte ${ }^{2}$, Marco A. Lardies ${ }^{3}$, Bernardo R. \\ Broitman $^{4}$, Christian Tapia ${ }^{5}$, Pamela Tapia ${ }^{5}$, Steve Widdicombe ${ }^{6}$, Cristian A. Vargas $^{7}$ \\ ${ }^{1}$ Centro de Investigación e Innovación para el Cambio Climático (CiiCC), Facultad de Ciencias, Universidad Santo Tomás, 8370003 \\ Santiago, Chile \\ ${ }^{2}$ Departamento de Ecología y Biodiversidad, Facultad de Ecología y Recursos Naturales, Universidad Andrés Bello, \\ 8370251 Santiago, Chile \\ ${ }^{3}$ Facultad de Ingeniería \& Ciencias y Facultad de Artes Liberales, Universidad Adolfo Ibáñez, 7941169 Santiago, Chile \\ ${ }^{4}$ Centro de Estudios Avanzados en Zonas Áridas (CEAZA), Universidad Católica del Norte, Larrondo 1281, 1781421 Coquimbo, Chile \\ ${ }^{5}$ Cultivos Invertec Ostimar S.A., Tongoy, 1780000 Coquimbo, Chile \\ ${ }^{6}$ Plymouth Marine Laboratory, Prospect Place, West Hoe, PL1 3DH Plymouth, UK \\ ${ }^{7}$ Laboratorio de Funcionamiento de Ecosistemas Acuáticos (LAFE), Departamento de Sistemas Acuáticos, \\ Facultad de Ciencias Ambientales, Universidad de Concepción, 4070386 Concepción, Chile
}

\begin{abstract}
Coastal upwelling regions already constitute hot spots of ocean acidification as naturally acidified waters are brought to the surface. This effect could be exacerbated by ocean acidification and warming, both caused by rising concentrations of atmospheric $\mathrm{CO}_{2}$. Along the Chilean coast, upwelling supports highly productive fisheries and aquaculture activities. However, during recent years, there has been a documented decline in the national production of the native scallop Argopecten purpuratus. We assessed the combined effects of temperature and $p \mathrm{CO}_{2}$-driven ocean acidification on the growth rates and shell characteristics of this species farmed under the natural influence of upwelling waters occurring in northern Chile $\left(30^{\circ} \mathrm{S}\right.$, Tongoy Bay). The experimental scenario representing current conditions $\left(14^{\circ} \mathrm{C}, \mathrm{pH} \sim 8.0\right)$ were typical of natural values recorded in Tongoy Bay, whilst conditions representing the low $\mathrm{pH}$ scenario were typical of an adjacent upwelling area ( $\mathrm{pH} \sim 7.6)$. Shell thickness, weight, and biomass were reduced under low $\mathrm{pH}(\mathrm{pH} \sim 7.7)$ and increased temperature $\left(18^{\circ} \mathrm{C}\right)$ conditions. At ambient temperature $\left(14^{\circ} \mathrm{C}\right)$ and low $\mathrm{pH}$, scallops showed increased shell dissolution and low growth rates. However, elevated temperatures ameliorated the impacts of low $\mathrm{pH}$, as evidenced by growth rates in both $\mathrm{pH}$ treatments at the higher temperature treatment that were not significantly different from the control treatment. The impact of low $\mathrm{pH}$ at current temperature on scallop growth suggests that the upwelling could increase the time required for scallops to reach marketable size. Mortality of farmed scallops is discussed in relation to our observations of multiple environmental stressors in this upwelling-influenced area.
\end{abstract}

KEY WORDS: Calcification · Shell growth · Scallop farming · Upwelling · Chile

\section{INTRODUCTION}

The increasing concentration of carbon dioxide $\left(\mathrm{CO}_{2}\right)$ in the atmosphere due to anthropogenic activities has triggered major changes in the global cli-

\footnotetext{
${ }^{*}$ Corresponding author: nlagoss@santotomas.cl
}

mate system, leading to increased global mean temperatures (i.e. global warming) of approximately $0.7^{\circ} \mathrm{C}$, a trend that will continue and fluctuate over a broad range $\left(1-4^{\circ} \mathrm{C}\right)$ towards the end of the century (IPCC 2014). These changes in the thermal environ- 
ment may influence the distribution and abundances of the marine biota through challenges to the ecophysiological capabilities of different organisms (Helmuth et al. 2006). However, environmental changes due to warming alone are only one of a set of possible interacting climatic variables that will drive ecological and evolutionary responses in marine ecosystems (Harley et al. 2006). Rising atmospheric $\mathrm{CO}_{2}$ levels are also driving an increased uptake of $\mathrm{CO}_{2}$ into the ocean, which in turn produces a series of changes to the carbonate chemistry of seawater, a process now well established as ocean acidification (Caldeira \& Wickett 2003, Orr et al. 2005, Gattuso et al. 2015). Ocean acidification (OA) negatively affects a variety of marine calcifying organisms by reducing calcification rates or by increasing the dissolution of calcareous structures (Fabry et al. 2008, Doney et al. 2009, Ries et al. 2009, Gazeau et al. 2013, Kroeker et al. 2013). Studies of mollusks specifically have suggested that the negative impacts of OA include reduced shell mass along with compromised shell structural integrity and strength (Buschbaum et al. 2007, McClintock et al. 2009, Welladsen et al. 2010, Bressan et al. 2014, Duarte et al. 2014, Fitzer et al. 2014, Mackenzie et al. 2014). However, the responses of different species and populations are highly variable when the impacts of OA are assessed in combination with warming and other stressors such as salinity and oxygen (e.g. Duarte et al. 2014, 2015, Ko et al. 2014). Thus, the combined effects of $\mathrm{OA}$ and warming on commercial shellfish species are of growing concern given that mollusks represent an important source of global seafood production (Branch et al. 2013). In addition, as global warming and OA are occurring concomitantly, affecting many physiological processes of marine organisms, their combined effects must be evaluated (Byrne \& Przeslawski 2013).

Shellfish aquaculture is reliant on growing individuals at high densities, meaning that shell robustness and size are important individual attributes with important implications for levels of production. Shell integrity is particularly important during the thinning process in which bivalves are physically handled as their densities are manipulated to reduce the interference in feeding so the scallops can grow faster to market size (e.g. Fréchette et al. 2010, Cubillo et al. 2012). OA and warming could also have implications for decision-making processes associated with the adequate timing of release of hatchery-reared mollusks into nature (Jory \& Iversen 1988, Grefsrud \& Strand 2006). Thus, in addition to knowing how OA and warming may affect the ability of the shell to provide physical support for soft internal organs and defense against predators and/or other environmental stressors (Waldbusser et al. 2013), a knowledge of how shell characteristics may change under future environmental conditions is crucial information for underpinning the future management strategies employed by the aquaculture industry (e.g. Grefsrud \& Strand 2006, Welladsen et al. 2010, Mackenzie et al. 2014).

The aquaculture industry relies on key ecosystem services provided by the coastal ocean, where most shellfish production takes place. Larval production in onshore hatcheries provides some control over the natural variability observed in coastal waters, such as food content and water temperature, but they are transferred as juveniles to the natural environment, where they are reared until harvest. However, the carbon chemistry of seawater is also subject to natural variability, especially in coastal upwelling areas, where it may negatively impact aquaculture production (Barton et al. 2012). In northern Chile, the fishery of the native scallop Argopecten purpuratus (Mollusca; Bivalvia; Pectinidae) collapsed during the mid-1980s following overexploitation of natural stocks. The fishery is still banned and was replaced by production from suspended culture activities, although current production only represents a fraction (10-15\%) of the historical national landings (Stotz 2000). During the last decade, the Chilean landings of mollusks in general have ranged from 300000 to 550000 t. Over the same period, the production of scallops showed a decreasing trend, with the production in 2014 being equivalent to only $20 \%$ of the landings recorded $10 \mathrm{yr}$ before (SERNAPESCA 2014; Fig. 1). This reduction in scallop production is challenging

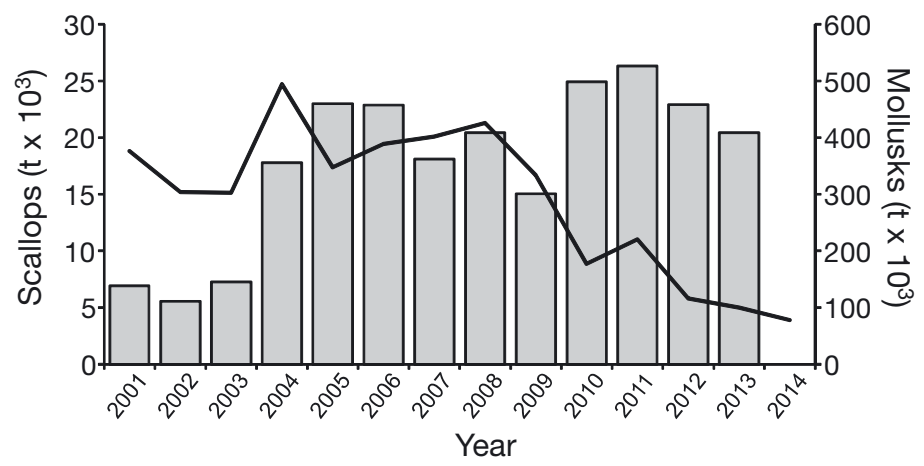

Fig. 1. Landings of Argopecten purpuratus (black line) and total mollusks harvested in Chile for the period 2001 to 2014 (source: Servicio Nacional de Pesca, www.sernapesca.cl; accessed 4 June 2015) 
the sustainability of this socio-economic sector in northern Chile, thus highlighting the need to perform studies aimed at understanding causes of this reduction and to provide information to support mitigation and adaptation strategies. For example, studies carried out with the mussel Mytilus chilensis, the most widely cultivated species in Chile, showed that OA, but not temperature increase, will decrease the biomass production of this highly valuable bivalve by $30 \%$ (Navarro et al. 2013, Duarte et al. 2014, 2015).

The commercial production of A. purpuratus is currently restricted to aquaculture activities which use suspended cultures in natural embayments, with northern Chile and Tongoy Bay $\left(30^{\circ} 12^{\prime} \mathrm{S}, 71^{\circ} 34^{\prime} \mathrm{W}\right.$, Fig. 2) being among the most important locations for scallop aquaculture along the Chilean coast (Thiel et al. 2007). Tongoy Bay is located ca. $10 \mathrm{~km}$ north of the Pt. Lengua de Vaca upwelling center $\left(30^{\circ} \mathrm{S}\right.$, Fig. 2). The bay is part of the highly productive Coquimbo upwelling system, which is characterized by the presence of cold, $\mathrm{CO}_{2}$-enriched, and poorly oxygenated waters, particularly during the spring and summer months (Thiel et al. 2007). More recent evidence suggests that this upwelling area is naturally acidified and characterized by low $\mathrm{pH}$ levels and a

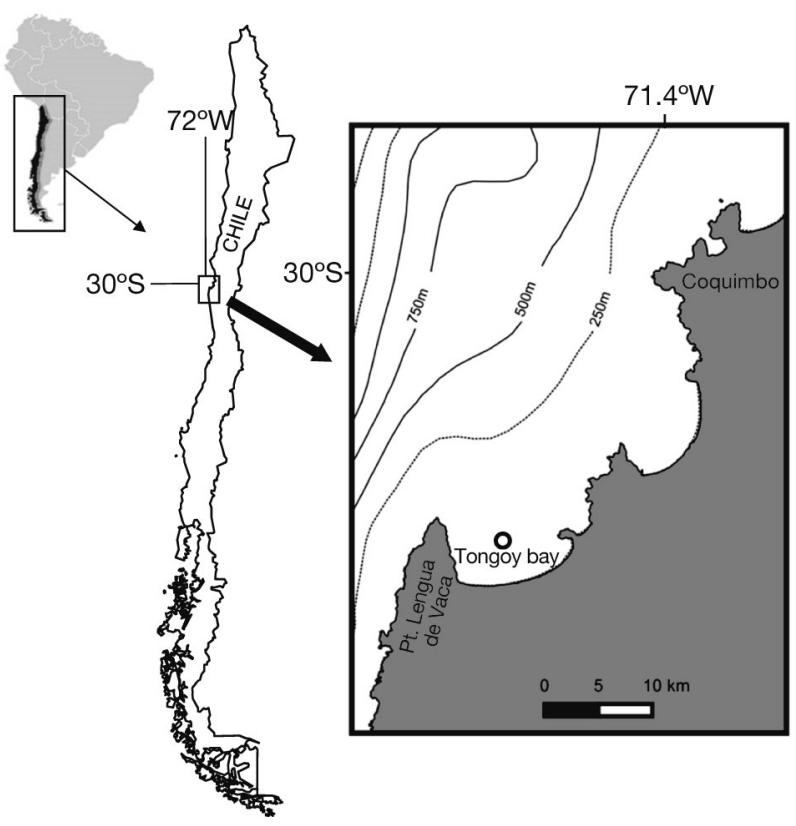

Fig. 2. Geographic location of Tongoy Bay and Pt. Lengua de Vaca upwelling center. The circle indicates the location of the CEAZAMET buoy, which is moored adjacent to the aquaculture facilities of the Invertec-Ostimar aquaculture company low carbonate saturation state (Torres \& Ampuero 2009). These conditions are similar to projections of progressive acidification in other eastern boundary coastal upwelling areas, such as off the coasts of Oregon and California, USA (Feely et al. 2008, Gruber et al. 2012). This environmental pattern implies that the sustainability of the shellfish aquaculture industry within Tongoy Bay could be vulnerable to the penetration of corrosive waters upwelled at Pt. Lengua de Vaca.

Upwelling is intensifying in eastern boundary current systems (Sydeman et al. 2014), particularly in the Oregon-California and Humboldt systems, which may further increase the intrusion of corrosive waters in the coastal domain. This ongoing global trend emphasizes the challenge of establishing a coherent scientific basis with which to predict the response of specific aquaculture species living in regions subject to upwelling disturbances (Barton et al. 2012, Ekstrom et al. 2015). The current study represents the first effort specifically aimed at experimentally evaluating the combined effects of temperature and OA upon the native scallop $A$. purpuratus cultured under the influence of upwelling waters. A range of biological responses were measured, including calcification rates, shell dissolution, shell thickness, dry shell weight, and tissue biomass. These results are discussed in relation to updated information on the physical-chemical variability inside Tongoy Bay and events of in situ mortality of $A$. purpuratus observed in the commercial aquaculture operations in the bay.

\section{MATERIALS AND METHODS}

\section{Scallop collection}

Juvenile individuals of Argopecten purpuratus ( $\sim 41 \mathrm{~mm} \pm 1.3 \mathrm{SD}$ in shell length) were obtained on 20 August 2014, from suspended culture facilities (ca. $2 \mathrm{~m}$ depth) belonging to the at-sea commercial aquaculture production operations from Invertec-Ostimar Co. located in Tongoy Bay (Fig. 1). After collection, scallops were transported in a thermobox $\left(\mathrm{ca} .14^{\circ} \mathrm{C}\right.$, emersed but wet conditions) to the Calfuco Coastal Laboratory (Valdivia, Chile) and aquaria (9 l, 15-20 scallops per aquarium). Before the experimental period, scallops were kept for $3 \mathrm{~d}$ in running seawater (ca. $\left.13-14^{\circ} \mathrm{C}\right)$, with natural photoperiod, and fed daily with microalgae (Tetraselmis spp., $\sim 65 \times 10^{6}$ cells ml-1) to allow the scallops to acclimate to laboratory conditions. 


\section{Experimental setup}

To examine the effects of $\mathrm{pH}$ and temperature, 4 experimental treatments were selected: (1) present-day conditions (control): $14^{\circ} \mathrm{C}$ and $\mathrm{pH} \sim 8.0$; (2) control temperature $\left(14^{\circ} \mathrm{C}\right)$ and low $\mathrm{pH}(\sim 7.7)$; (3) high temperature $\left(18^{\circ} \mathrm{C}\right)$ and control $\mathrm{pH}$; (4) high temperature and low $\mathrm{pH}$. Control conditions in temperature represent annual average sea surface temperature $\left(14^{\circ} \mathrm{C}\right.$, a value currently recorded during the scallop collection, see 'Results'), whereas high temperature, in addition to the projected increase in $4^{\circ} \mathrm{C}$ (IPCC 2014), represents the maximum surface temperature $\left(18^{\circ} \mathrm{C}\right)$ reported for Tongoy Bay (Aravena et al. 2014). The temperature of each treatment was stabilized using external chillers $\left( \pm 0.1^{\circ} \mathrm{C}\right)$. To obtain the different $\mathrm{pH}$ scenarios, the methodology previously described by Torres et al. (2013) (see Navarro et al. 2013, Duarte et al. 2014, 2015) was followed. Briefly, for present-day conditions (i.e. $\sim 390$ patm $p \mathrm{CO}_{2}$ in seawater), atmospheric air was bubbled into experimental aquaria and head tanks; for a low $\mathrm{pH}$ scenario, blended dry air was generated by compressing atmospheric air (117 psi) using an oil-free compressor with pure $\mathrm{CO}_{2}$ using mass flow controllers (MFCs, Aalborg ${ }^{\mathrm{TM}}$ ); this blend was then bubbled into experimental aquaria and head tanks reaching $\sim 900 \mu \mathrm{atm} p \mathrm{CO}_{2}$ in seawater. The seawater of each aquarium was replaced every $2 \mathrm{~d}$ using the pre-equilibrated seawater from the head tank. In the current experimental system, this increase in $p \mathrm{CO}_{2}$ in seawater resulted in a corresponding drop in $\mathrm{pH}$ ( $\sim 0.3$ units) yielding a target $\mathrm{pH}$ level of $\sim 7.7$ for the low $\mathrm{pH}$ scenario, while the presentday $\mathrm{pH}$ level remained at $\sim 8.0$ units (Table 1 ). These $p \mathrm{CO}_{2}$ levels in seawater were selected taking into account the rate of change projected for the atmospheric $\mathrm{CO}_{2}$ by the year 2100, consistent with the IPCC A2 emission scenario (e.g. Meinshausen et al. 2011, IPCC 2014).

Four scallops were randomly assigned to each of 20 aquaria (9 l), and each aquarium was then randomly assigned to a pH/temperature treatment following a systematic design, with each treatment being replicated 5 times. All animals were labeled using bee tags glued to the shell. In addition, 1 empty shell of $A$. purpuratus of similar size to those in the experimental aquaria, previously tagged and weighed, was placed in each container to provide an estimate of net shell dissolution in each treatment. Beforehand, dead shells were cleaned with distilled water and then dried for $24 \mathrm{~h}\left(60^{\circ} \mathrm{C}\right)$ until constant dry weight. Before assigning individuals to experimental treatments, live animals were characterized in terms of their shell length, shell height, and buoyant weight. There were no statistical differences across treatments in these shell characteristics at the beginning of the experiments (1-way ANOVA, p > 0.05 in all cases). The exposure period lasted for $18 \mathrm{~d}$, and scallops were fed daily with Tetraselmis spp. and maintained under natural photoperiod conditions, as in the previous acclimation period.

\section{Carbonate system parameter monitoring}

The seawater in each aquarium was gently replaced every day, with the corresponding seawater pre-equilibrated at the target $p \mathrm{CO}_{2}$ levels in the head tank. Over the experimental period, $\mathrm{pH}$ and total alkalinity $\left(\mathrm{A}_{\mathrm{T}}\right)$ were monitored on Days $2,6,10$, 14 , and 18 to estimate carbonate system parameters. Samples for $\mathrm{pH}$ were collected in $50 \mathrm{ml}$ syringes, avoiding formation of bubbles during collection and handling of the sample, and immediately transferred

Table 1. Carbonate system parameters (mean \pm SE) registered at each experimental treatment combining present-day (low $p \mathrm{CO}_{2} / \mathrm{pH} \sim 8.0$ ) and future acidification conditions (high $p \mathrm{CO}_{2} / \mathrm{pH} \sim 7.7$ ) with temperatures dominating in Tongoy Bay, Chile, during the experimental period $\left(14^{\circ} \mathrm{C}\right)$ and under warmer conditions $\left(18^{\circ} \mathrm{C}\right)$. NBS: National Bureau of Standards

\begin{tabular}{|c|c|c|c|c|}
\hline \multirow{2}{*}{$\begin{array}{l}\text { Carbonate system } \\
\text { parameter }\end{array}$} & \multicolumn{2}{|c|}{$14^{\circ} \mathrm{C}$} & \multicolumn{2}{|c|}{$-18^{\circ} \mathrm{C}-$} \\
\hline & $\mathrm{pH} \sim 8.0$ & $\mathrm{pH} \sim 7.7$ & $\mathrm{pH} \sim 8.0$ & $\mathrm{pH} \sim 7.7$ \\
\hline Temperature $\left({ }^{\circ} \mathrm{C}\right)$ & $14.13 \pm 0.19$ & $14.08 \pm 0.14$ & $18.13 \pm 0.11$ & $18.14 \pm 0.13$ \\
\hline Salinity (PSU) & $34.48 \pm 1.78$ & $35.36 \pm 0.50$ & $33.28 \pm 1.97$ & $34.00 \pm 0.68$ \\
\hline $\mathrm{pH}_{\mathrm{NBS}}$ & $8.058 \pm 0.017$ & $7.754 \pm 0.027$ & $8.032 \pm 0.041$ & $7.720 \pm 0.021$ \\
\hline Total alkalinity $\left(\mu \mathrm{mol} \mathrm{kg}{ }^{-1}\right)$ & $1580.41 \pm 206.40$ & $1778.14 \pm 127.82$ & $1666.75 \pm 117.55$ & $1695.96 \pm 133.49$ \\
\hline $\mathrm{CO}_{3}^{-2}\left(\mu \mathrm{mol} \mathrm{kg}{ }^{-1}\right)$ & $86.54 \pm 10.15$ & $53.76 \pm 5.58$ & $94.76 \pm 3.92$ & $52.13 \pm 5.07$ \\
\hline$p \mathrm{CO}_{2}(\mu \mathrm{atm})$ & $367.77 \pm 62.17$ & $891.26 \pm 77.76$ & $435.96 \pm 74.43$ & $969.48 \pm 74.27$ \\
\hline$\Omega_{\text {calcite }}$ & $2.07 \pm 0.24$ & $1.28 \pm 0.13$ & $2.29 \pm 0.09$ & $1.25 \pm 0.13$ \\
\hline$\Omega_{\text {aragonite }}$ & $1.32 \pm 015$ & $0.82 \pm 0.09$ & $1.48 \pm 0.06$ & $0.81 \pm 0.08$ \\
\hline
\end{tabular}


to a $25 \mathrm{ml}$ thermostated closed cell at $25.0 \pm 0.1^{\circ} \mathrm{C}$ for standardization (DOE 1994, Torres et al. 2013), using a Metrohm ${ }^{\circledR} \mathrm{pH}-$ meter with a glass combined double junction $\mathrm{Ag} / \mathrm{AgCl}$ electrode (Metrohm model 6.0258.600) calibrated with standard buffer of $\mathrm{pH} 4$ (Metrohm® 6.2307.200), pH 7 (6.2307.210), and pH 9 (6.2307.220). pH values are reported on the National Bureau of Standards scale. Samples for $\mathrm{A}_{\mathrm{T}}$ were poisoned with $50 \mu$ of saturated $\mathrm{HgCl}_{2}$ solution and stored in $500 \mathrm{ml}$ borosilicate bottles (Pyrex, Corning(®) with ground-glass stoppers lightly coated with Apiezon L® grease and stored in the dark at room temperature. Additionally, temperature and salinity were monitored during incubations by using a portable Salinometer (Salt6+, Oakton ${ }$, accuracy: $\pm 1 \%$ and $\pm 0.5^{\circ} \mathrm{C}$, respectively). $\mathrm{A}_{\mathrm{T}}$ was determined using the open-cell titration method (Dickson et al. 2007) using an automatic alkalinity titrator (Model AS-ALK2 Apollo SciTech) equipped with a combination $\mathrm{pH}$ electrode (8102BNUWP, Thermo Scientific) and temperature probe (Star ATC, Thermo Scientific) connected to a pH meter (Orion Star A211, Thermo Scientific). All samples were analyzed at $25^{\circ} \mathrm{C}$ $\left( \pm 0.1^{\circ} \mathrm{C}\right)$ with temperature regulated using a water bath (Lab Companion CW-05G). Accuracy was controlled against a certified reference material (CRM; batch no. 140 supplied by A. Dickson, University of California, San Diego, CA). Every sample was analyzed with 2 or 3 replicates, and an accuracy of 2 to $3 \mu \mathrm{mol} \mathrm{kg} \mathrm{kg}^{-1}$ was observed with respect to CRM. Temperature and salinity data were used to calculate the rest of the carbonate system parameters (e.g. $p \mathrm{CO}_{2}, \mathrm{CO}_{3}{ }^{2-}$ ) and the saturation stage of aragonite $\left(\Omega_{\text {aragonite }}\right)$ and calcite $\left(\Omega_{\text {calcite }}\right)$. Analyses were performed using CO2SYS software for MS Excel (Pierrot et al. 2006) set with Mehrbach solubility constants (Mehrbach et al. 1973) refitted by Dickson \& Millero (1987). The $\mathrm{KHSO}_{4}$ equilibrium constant determined by Dickson (1990) was used for all calculations (Table 1).

\section{Biological responses}

At the end of the experimental period, shell thickness (mm) was measured and averaged over 3 measurements taken between the ribs located at the posterior region of scallop shells (i.e. the edge of the newly deposited shell; Bibby et al. 2007, Thomsen et al. 2010, Bressan et al. 2014). The tissue was removed and the final dry shell weight (mg) was measured after drying the shell at $60^{\circ} \mathrm{C}$ overnight (Binder) and then weighed in an analytical balance (to the nearest
$0.01 \mathrm{mg}$, Mettler Toledo). Because potential problems of water held in the shell and soft tissues, the final wet biomass was described using a relative index estimated as the difference between total and buoyant weight (see below), and expressed as a percentage of the total weight. Relative indexes are traditionally used to describe bivalve quality under aquaculture conditions (e.g. Maguire et al. 1999, Filgueira et al. 2013). Individual growth rates based on shell height (length perpendicular to the hinge) and length were estimated based on measurements performed (to the nearest $0.01 \mathrm{~m}$ using a Mitutoyo® caliper) on Days 1 and 18 of the experiment. Measurements of both shell height and length are used routinely during the thinning process of scallops in commercial aquaculture operations (Hennen \& Hart 2012). In addition, calcification and dissolution rates (see also Gazeau et al. 2015) were estimated from changes in the buoyant weight of individual scallops and changes in empty shell weight recorded on Days 1 and 18 of the experiment using an analytical balance. Briefly, the buoyant weight is a non-destructive technique useful to estimate the shell weight in gastropods, where the whole animal is immersed in seawater (Palmer 1982). Due to differences in specific gravity of shell and tissue, when immersed in seawater the mass of the animal is mainly accounted for by the shell. In addition, buoyant weight increment is an important proxy for growth because it is equivalent to the calcification rate and is not affected by the amount of seawater and tissue weight (Palmer 1982). However, the changes in empty shell weight used as a proxy of shell dissolution must be interpreted with caution (Nienhuis et al. 2010), given the role of organic layers such as the shell periostracum in protecting live animals from dissolution (Tunnicliffe et al. 2009). To avoid errors from air trapped inside the animals during the measurements of buoyant weight, each specimen was gently moved from the rearing container to the analytical balance. Following this procedure, only seawater remained within the valves and yielded consistent buoyant weights for the experimental specimens. The relationship between dry shell weight (SW) and buoyant weight (BW) was verified by constructing the scaling relationship between both variables using an additional batch of scallops encompassing all sizes available from the Invertec-Ostimar farm $\left(\log _{10} \mathrm{SW}=0.1995+0.9950\right.$ $\left.\log _{10} B W ; n=71 ; p<0.001 ; r^{2}=0.99\right)$. This methodology was successfully validated previously for the mussel Mytilus chilensis (Duarte et al. 2014). No mortality was recorded in any treatment during the experimental period. 


\section{In situ biological and environmental monitoring}

During July 2014, the Center for Advanced Research in Arid Zones (CEAZA) in collaboration with the Invertec-Ostimar Co. monitored water quality parameters in Tongoy Bay in close proximity to the area of scallop farming. This monitoring involved the deployment (10 $\mathrm{m}$ depth) of a CTD SBE 16plus v2 RS232 (Sea-Bird Electronics) measuring conductivity $\left(\mathrm{S} \mathrm{m}^{-1}\right)$, salinity (PSU), temperature $\left({ }^{\circ} \mathrm{C}\right)$, and dissolved oxygen $\left(\mathrm{mg} \mathrm{l}^{-1}, \mathrm{ml} \mathrm{l}^{-1}\right.$, and \% saturation) every $15 \mathrm{~min}$ (www.ceazamet.cl/index.php? pag=mod_estacion\&e_cod=BTG). In this study, the environmental data from July to December 2014 are summarized, jointly with estimates of the cumulative mortality of scallops for several size ranges recorded during the thinning process performed by the Invertec-Ostimar Company. The thinning process consists of a mechanical separation of scallops, reducing density to make room for those remaining in order to ensure better growth and productivity of the individuals (Maguire et al. 1999, Filgueira et al. 2013). During the thinning process, individuals that have died during the growing period are also removed. In this study, we report the cumulative mortalities recorded after 4 to 5 mo of growing period for 4 shell range sizes (i.e. $7-15$ to $45-50 \mathrm{~mm}$ in shell height), and their corresponding densities (i.e. from 200 to 25 scallops per lantern level). The adult fraction of the scallops size range corresponds to individuals between 45 and $50 \mathrm{~mm}$, which are cultivated at densities of 25 individuals on each level of the lanterns. The harvest is performed when the scallop shell sizes reach 65 to $70 \mathrm{~mm}$. During December 2014, the first-ever survey of carbonate system parameters $\left(\mathrm{pH}_{\mathrm{T}}, \mathrm{A}_{\mathrm{T}}\right.$, and estimates of $p \mathrm{CO}_{2}$ and $\left.\Omega\right)$ within Tongoy Bay was conducted, using similar methodology as described above. However, in contrast to the monitoring techniques employed within the laboratory, the field monitoring campaign used seawater buffer supplied by CRM, and $\mathrm{pH}$ was computed on the 'total' hydrogen scale $\left(\mathrm{pH}_{\mathrm{T}}\right)$. This study only presents the $\mathrm{pH}_{\mathrm{T}}$ and temperature data, and more environmental field data will be published elsewhere.

\section{Statistical analyses}

In each analysis, the replicate was the average response of the 4 scallops in each tank. Differences between treatments in scallop shell thickness and dry shell weight recorded at the end of the experi- ment were tested using ANCOVA models, including the final measurement of shell length and buoyant weight as covariates, respectively, in order to control for the inherent positive scaling relationship between shell length and both shell weight and thickness. ANCOVA results evidenced no significant influence of the shell length upon scallop shell thickness (covariate, $F_{1,15}=1.74 ; \mathrm{p}=0.207$ ), but a significant influence of buoyant weight upon dry shell weight (covariate, $F_{1,15}=82.69 ; \mathrm{p}<0.001$ ). In this case, further comparisons among treatments were done estimating the predicted value (least square mean) of the regression between dry shell weight with buoyant weight, and comparing them at the mean value of this covariate $\left(3.681 \mathrm{~g} \pm 0.37 \mathrm{SD}_{\text {; }}\right.$ see also Watson et al. 2012). Two-way ANOVAs were used to evaluate whether temperature, $\mathrm{pH}$ levels, or the interaction between factors affected the measured biological responses (biomass, shell growth, calcification, and shell dissolution rates) during the experiment. Tukey's HSD was used as an a posteriori test when the main factors indicated significant differences between levels of the corresponding factor (Underwood 1997). These ANOVAs were implemented in a generalized linear model and the coefficient of the interaction term was estimated. Positive or negative coefficients for significant interaction terms were interpreted as synergistic or antagonistic effects between temperature and $\mathrm{pH}$ upon the corresponding biological response (Kroeker et al. 2013). Only growth rates based on shell length and height required $\log _{10}$ transformation to meet ANOVA assumptions. In both ANOVA and ANCOVA, normality was assessed over model residuals using the Kolmogorov-Smirnov test, and homoscedasticity was evaluated using Bartlett tests (Sokal \& Rohlf 1995). Finally, a $\chi^{2}$ test on scallop cumulative mortality data recorded in the sea farm was used to test whether, over time (month), mortalities were dependent on the shell range sizes used in the scallop thinning process. All analyses were carried out using Minitab v14.

\section{RESULTS}

The experimental setup and average environmental and carbonate chemistry parameters recorded during the experiments with Argopecten purpuratus are shown in Table 1. Low $\mathrm{A}_{\mathrm{T}}$ values were observed for all treatments $\left(<2000 \mu \mathrm{mol} \mathrm{kg}{ }^{-1}\right)$, due to the influence of riverine discharges (Valdivia River Estuary) close to the coastal laboratory (Torres et al. 2013). 
$p \mathrm{CO}_{2}$ values ranged from 367 to 435 $\mu$ atm for the low $p \mathrm{CO}_{2}$ treatment at 14 and $18^{\circ} \mathrm{C}$, respectively, and from 891 to $969 \mu \mathrm{atm}$ for the high $p \mathrm{CO}_{2}$ at 14 and $18^{\circ} \mathrm{C}$, respectively. $\Omega_{\text {aragonite }}$ varied less between temperatures, but undersaturation was reached under the high $p \mathrm{CO}_{2}$ treatment ( $\Omega_{\text {aragonite }}$ from 0.81 to 0.82 ; Table 1 ).

At the end of the experimental period, shell thickness, dry shell weight, and wet biomass of the scallops were significantly lower in the treatments representing combinations of low $\mathrm{pH}$ levels at increased temperature when compared with current environmental conditions (i.e. $14^{\circ} \mathrm{C}$ and $\mathrm{pH} \sim 8.0$; Fig. 3). These patterns of variability were dominated by differences in temperature among treatments and to a lesser extent to $\mathrm{pH}$ variability (Table 2 ). Thus, thicker and heavier shells and increased biomass were observed on scallops growing under current environmental conditions when compared with all other combinations of temperatures and $\mathrm{pH}$ level (Tukey HSD, $\mathrm{p}<$ 0.05).

Control or current temperature $\left(\sim 14^{\circ} \mathrm{C}\right)$ and low $\mathrm{pH}$ $(\sim 7.7)$ significantly restricted the shell growth in length and height (Table 2, Tukey HSD, p $<0.05$, Fig. 4), but elevated temperatures appeared to ame-
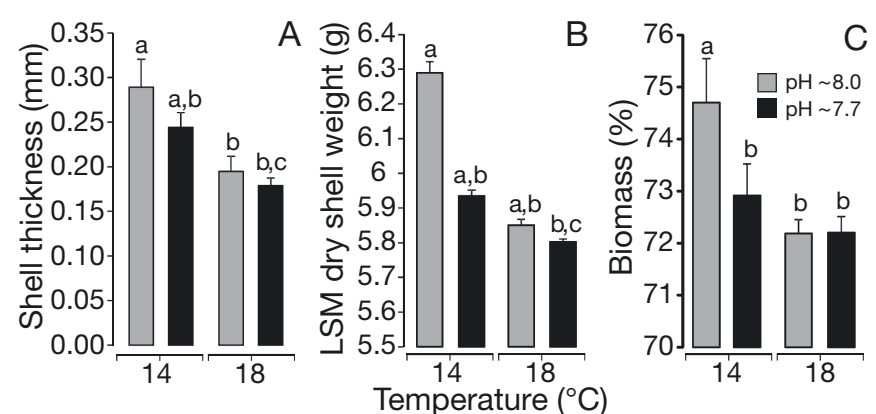

Fig. 3. Mean $\pm \mathrm{SE}(\mathrm{A})$ shell thickness, (B) dry shell weight, and (C) wet biomass of Argopecten purpuratus reared at nominal $\mathrm{pH}$ levels in seawater and at 2 temperatures. All measurements were recorded at the end of the study period (18 d). LSM: least square mean, which corresponds to the predicted value of dry shell weight at the mean value of buoyant weight, used as covariate in an ANCOVA model (see 'Materials and methods'). Different letters indicate significant differences among treatments $(n=5)$ using a post hoc Tukey HSD test liorate the negative impacts of reduced $\mathrm{pH}$ (i.e. combination $\mathrm{pH} \sim 7.7 / 18^{\circ} \mathrm{C}_{\text {; Fig. }}$ ). Temperature and $\mathrm{pH}$ showed a significant and positive interaction term (coefficient $=0.0104 \pm 0.0041 \mathrm{SE}$; Table 2), thus indi-

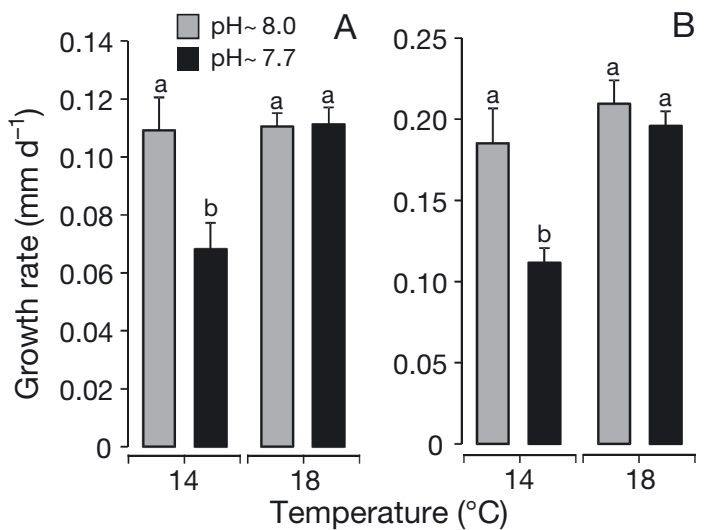

Fig. 4. Growth rates measured as increments in the shell height and length (mean $\pm \mathrm{SE}$ ) of Argopecten purpuratus individuals reared at 2 temperatures and 2 nominal $\mathrm{pH}$ levels in seawater. These rates were estimated based on the difference between initial and final measurements after the $18 \mathrm{~d}$ experimental period. Different letters indicate significant differences among treatments $(n=5)$ using a post hoc Tukey HSD test 
cating a synergistic effect of temperature and $\mathrm{pH}$ on the growth rate in shell height of the scallops. For the remaining biological responses, we found nonsignificant interactive effects of $\mathrm{pH}$ and temperature (Table 2).

The net calcification rate over the study period was not affected by low $\mathrm{pH}$, but temperature had a significant positive effect (Table 2, Fig. 5A). Shell dissolution, estimated from changes in shell weight of dead scallops, was significantly higher at the combination of low $\mathrm{pH}$ and at control temperature (i.e. $\mathrm{pH}$ $\sim 7.7 / 14^{\circ} \mathrm{C}_{i}$ Fig. $5 \mathrm{~B}$ ).

The monitoring program that started during 2014 provided updated information on the seawater properties of Tongoy Bay. In particular, during the experimental period (mid-August to mid-September), the seawater temperature measured at $10 \mathrm{~m}$ depth inside the bay ranged between 12 and $15^{\circ} \mathrm{C}$, with low levels of oxygen concentration $\left(3-6 \mathrm{ml} \mathrm{l}^{-1}\right)$ and low variability in salinity (ca. 34.4 psu; Fig. 6A-C). On 2 September, cooling events were observed that coincided with periods of oxygen depletion, with the second event displaying oxygen levels below $2 \mathrm{ml} \mathrm{l}^{-1}$, values that are consistent with a hypoxia event (Fig. 6B). During the rest of the year (October to December), the temperatures regularly fluctuated below $15^{\circ} \mathrm{C}$, with drops in temperature being concurrent with decreased levels of dissolved oxygen. From July to December 2014, the cumulative mortalities (integrating the last $4-5 \mathrm{mo}$ ) of scallops were dependent on shell size $\left(\chi^{2}=142, \mathrm{df}=15, \mathrm{p}<\right.$ 0.001, Fig. 6D). In particular, scallop mortality was reduced during September, but an important

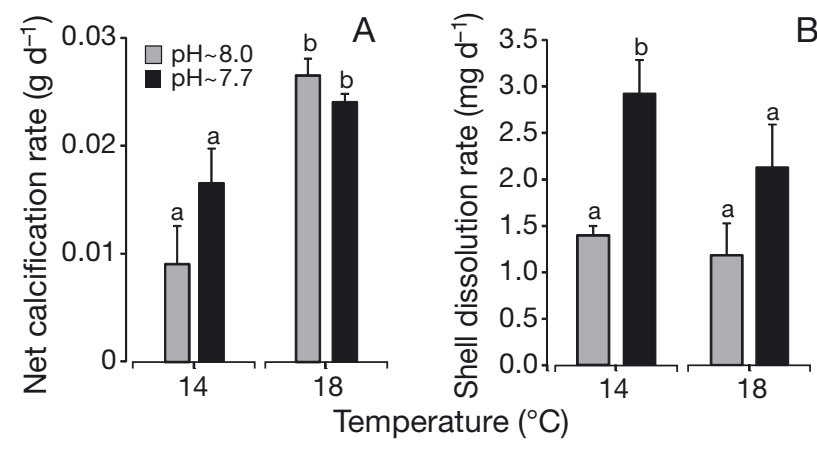

Fig. 5. (A) Net calcification rate (mean $\pm \mathrm{SE}$ ) of Argopecten purpuratus reared at 2 temperatures and 2 nominal $\mathrm{pH}$ levels in seawater. (B) Dissolution rate (mean $\pm \mathrm{SE}$ ) of dead shells of the scallops exposed to the same experimental conditions. These rates were estimated based on the difference between initial and final measurement after the $18 \mathrm{~d}$ experimental period. Different letters indicate significant differences among treatments $(n=5)$ using a post hoc Tukey HSD test

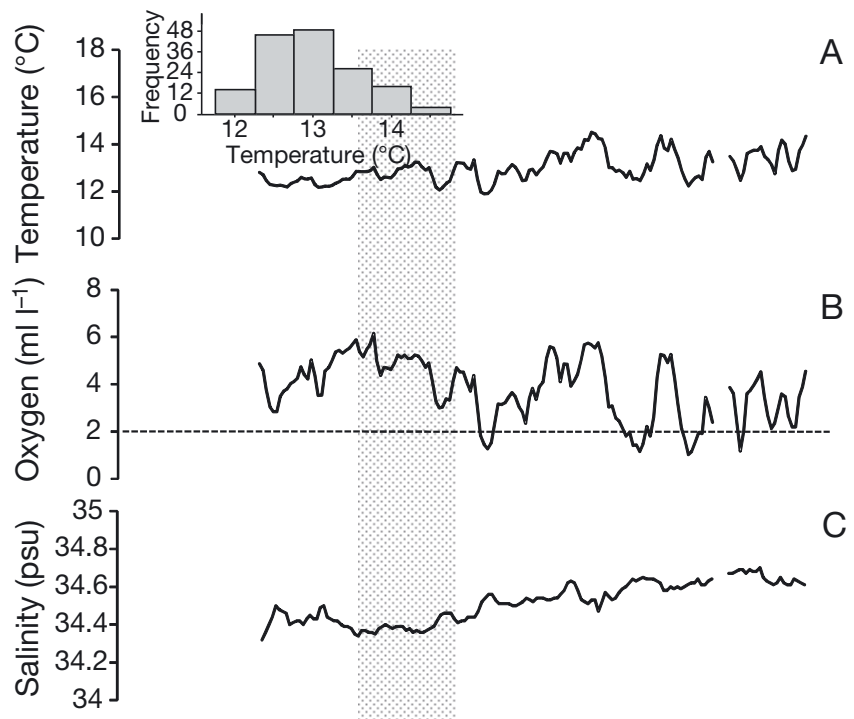

A

$B$

C

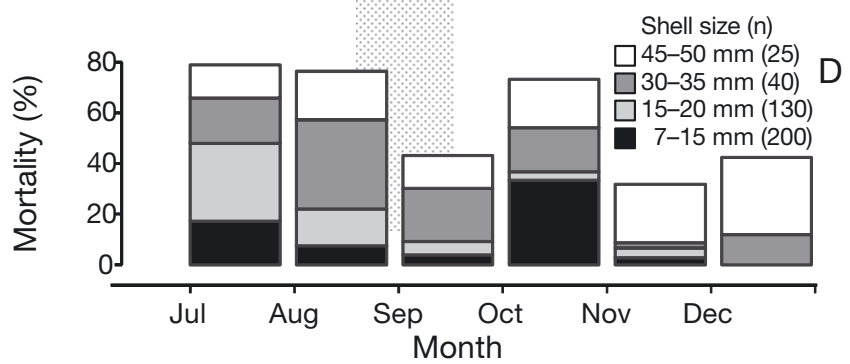

Fig. 6. Temporal fluctuations in (A) temperature, (B) oxygen concentration, and (C) salinity measured from June to December 2014 by the CEAZAMET buoy at $10 \mathrm{~m}$ depth in Tongoy Bay. (D) Cumulative mortalities in 4 shell range sizes of Argopecten purpuratus recorded during the scallop thinning procedure performed from July to December 2014 at the Invertec-Ostimar Co. scallop farm; each growing period lasted for ca. 4 to $5 \mathrm{mo}$. The initial number of scallops at each level of the lantern nets and in each size range (see 'Materials and methods') is shown in brackets. Inset in (A) shows the histogram for temperature observations recorded during the study period; the horizontal dashed line in (B) indicates hypoxia levels, and the stippled area represents the timing of the experimental period

increase in mortality was observed in October mostly in small scallops $(7-15 \mathrm{~mm})$. The mortality of scallops with larger shell sizes ( $>45 \mathrm{~mm}$ ) remained fairly constant (ca. 20-30\%) throughout the monitoring period (Fig. 6D).

\section{DISCUSSION}

Despite the short period of exposure used in our study (18 d), we detected significant effects of OA and temperature on juvenile individuals of Argopecten purpuratus; our results were similar to a previous study, in which a short exposure time was suf- 
ficient to detect OA and warming effects on this marine mollusk (Nienhuis et al. 2010, Duarte et al. 2014). These results suggest that $\mathrm{OA}$ and warming might have significant effects on the fitness of these individuals in a short period of time. This information is relevant to understand the effects of upwelling conditions on these animals, because this phenomenon is of short duration and is not constant. In this study, no mortality effects were found on juveniles in any of the experimental treatments, which indicates that the projected increase of $\mathrm{CO}_{2}$ levels and temperature had chronic, but not lethal, effects on these animals. This lack of mortality may result from an underlying natural tolerance of $A$. purpuratus to the changes in temperature and $\mathrm{pH}$ used in the current study, all of which fall within the extremes of environmental variability observed inside Tongoy Bay (see discussion below and Fig. 7).

Despite the lack of lethal effects, significant physiological responses to both temperature and $\mathrm{pH}$ changes were observed. Shell thickness, shell weight, and live biomass of A. purpuratus individuals were significantly reduced at low $\mathrm{pH}(\mathrm{pH} \sim 7.7)$ and increased temperature $\left(18^{\circ} \mathrm{C}\right)$ compared to control individuals $\left(\mathrm{pH}=8.0\right.$ at $\left.14^{\circ} \mathrm{C}\right)$. Reduced shell growth and increased dissolution rates were observed at

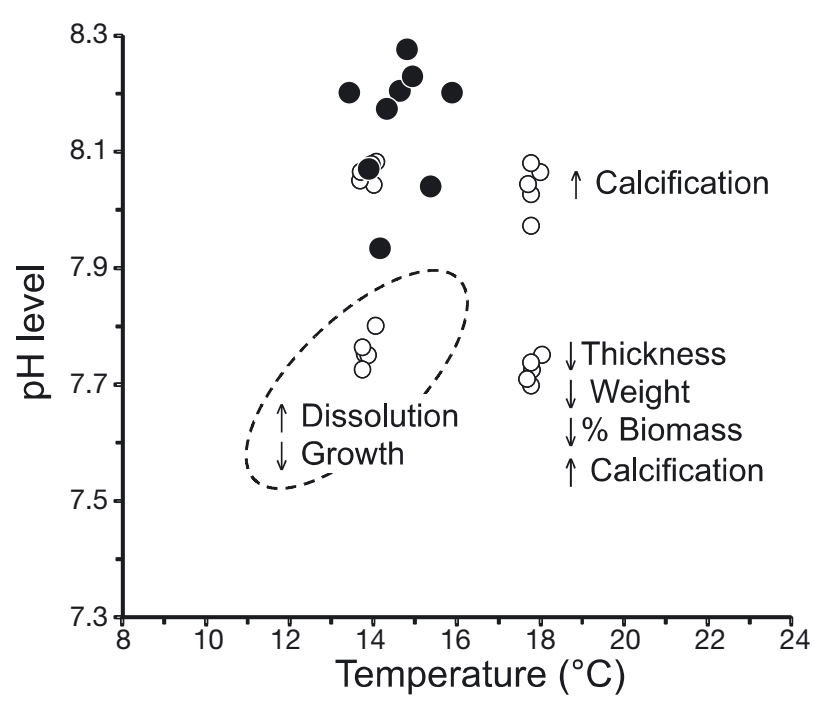

Fig. 7. Graphical summary for the variability of each temperature/pH combination in the experimental treatments (open circles); the natural variability in temperature/pH recorded inside Tongoy Bay in December 2014 (black dots) during a field survey, and the environmental range of $\mathrm{pH}$ and temperature reported for Pt. Lengua de Vaca upwelling area (dashed ellipse, see 'Discussion'). The significant effects recorded in each shell characteristic of Argopecten purpuratus are indicated by up or down arrows and presented beside each $\mathrm{pH} /$ temperature combination ambient temperature $\left(14^{\circ} \mathrm{C}\right)$ in low $\mathrm{pH}$ treatments. These dissolution rates fluctuated between 3 and $10 \%$ of net calcification, but did not preclude animal growth, as illustrated by increased shell length and weight across all treatments. Impacts of lowered $\mathrm{pH}$ were ameliorated at warmer temperatures $\left(18^{\circ} \mathrm{C}\right)$, through a significant increase in calcification rates. Thus, the results of this study agree with previous studies where shell characteristics, such as shell dissolution, shell size, and calcification rates, were used to examine the impacts of temperature and OA on marine calcifying organisms, and that warming could reverse the negative effects of OA (e.g. Beniash et al. 2010, Welladsen et al. 2010, Byrne 2012, Chan et al. 2013, Thomsen et al. 2013, Bressan et al. 2014, Fitzer et al. 2014). Although we did not assess additional biological sources of stress in the present study, they may also affect shell formation and structure. For instance, food limitation could be crucial if feeding rates increased beyond the food supply provided in this experiment (Mackenzie et al. 2014).

Significant reductions of shell thickness and weight (ca. $-36 \%$ and $-7 \%$, respectively) were observed under experimental conditions of low $\mathrm{pH}$ at $18^{\circ} \mathrm{C}$ with respect to control scallops (i.e. present-day conditions, $14^{\circ} \mathrm{C} / \mathrm{pH} \sim 8.0$ ). Such a response could have implications for the long-term survival of individuals, as shell strength in scallops is a function of shell height, thickness, corrugation, and convexity (Pennington \& Currey 1984). Lafrance et al. (2003) demonstrated that the shells of wild scallops were significantly heavier and stronger than those of cultured scallops, suggesting that cultured juvenile scallops have an increased vulnerability to shell-cracking predators. This reduction in shell strength was associated with factors related to the suspended culture (e.g. density, suspension depth, fouling, handling), leading to the study of mechanisms enhancing shell strength and strategies involving the timing of release of scallops into bottom culture (Grefsrud \& Strand 2006). Our study suggests that, in addition to factors related to suspended culture conditions, other stressors such as low seawater $\mathrm{pH}$ also influence the shell strength of $A$. purpuratus. Similar reductions in shell thickness and associated robustness have been described by several studies in other mollusks exposed to low pH conditions (Bibby et al. 2007, Gazeau et al. 2013). In particular, the larval shell of the scallop $A$. irradians decreased in thickness when exposed to the low $\mathrm{pH}$ (high $p \mathrm{CO}_{2}$ ) seawater conditions projected for the end of this century (Talmage \& Gobler 2010). However, other studies reported that mussels grew thicker shells at warmer temperatures 
independent of $\mathrm{pH}$ conditions (Mytilus galloprovincialis, Kroeker et al. 2013), or showed no reduction in shell thickness ( $M$. edulis, Thomsen et al. 2013). More recently, Bressan et al. (2014) pointed out that a reduction in shell thickness could be species specific and could take place after 3 and 6 mo of incubation under acidification conditions in clams Chamelea gallina and mussels $M$. galloprovincialis, respectively. Since low pH conditions can reduce the shell thickness in scallops, it is realistic to expect effects in areas, such as Tongoy Bay, that are under the influence of low pH upwelling waters (Torres \& Ampuero 2009, see below and Fig. 6). Thus, studies that aim to improve our understanding of the mechanisms that govern scallop shell strength and related mineralogical properties are urgently needed.

Reduced shell growth under acidified or low $\mathrm{pH}$ conditions have been reported specifically for scallops (Talmage \& Gobler 2009, White et al. 2013) and other mollusks (Melzner et al. 2011, Hiebenthal et al. 2013, Kroeker et al. 2013, Bressan et al. 2014). As in those studies, we found that a significant reduction in shell length and height of $A$. purpuratus occurs even though seawater remained above the saturation state for carbonate precipitation $\left(\Omega_{\text {calcite }}>1\right)$. In addition, our experimental scenarios are within the environmental conditions described as setting a threshold for negative effects of $\mathrm{pH}$ (7.5-7.4; Berge et al. 2006, Bressan et al. 2014) and temperature $\left(25^{\circ} \mathrm{C}\right)$ on shell growth of bivalves (Hiebenthal et al. 2013, Kroeker et al. 2013). Thus, to a lesser extent but also important, the reduction in shell growth of $A$. purpuratus may be ascribed to dissolution as recorded in dead shells exposed to low $\mathrm{pH}$ and low temperature conditions (Nienhuis et al. 2010, Duarte et al. 2014). In contrast to other materials, the kinetic dissolution/solubility of carbonate shells increases at low temperatures (Morse et al. 2007). This property of carbonates may help to explain the increase in shell calcification of $A$. purpuratus at warmer temperatures. However, saturation states were roughly similar across temperature treatments at respective $\mathrm{pH}$ levels. This suggests a major role for warmer temperatures, which could potentially offset the reduction in calcification caused by OA (Byrne \& Przeslawski 2013, Kroeker et al. 2013, Duarte et al. 2014). However, calcification must be regarded as part of the whole biology of the individuals and thus the reduction in shell increments under low $\mathrm{pH}$ could be because energy allocation is being diverted away to other key physiological processes such as acid-base balance, reproduction, and immune function (Wood et al. 2008, Findlay et al. 2009). Finally, the increment in the calcification rates at $18^{\circ} \mathrm{C}$ registered in our study (see Fig. 7 ) reinforces the notion that $A$. purpuratus can benefit from warmer temperatures and agrees with previous observations relating increased developmental rates and population abundances of $A$. purpuratus during El Niño - Southern Oscillation (ENSO) events which regularly impact upwelling ecosystems in northern Chile (Thiel et al. 2007). This finding indicates that scallop aquaculture in northern Chile will remain exclusively associated with embayment areas, where increased temperatures may provide a 'refuge' for scallop production.

Currently, there is no consensus of how the effects of warming and acidification will interact (e.g. additive, synergistic, or antagonistic) to influence the fitness of mollusks (e.g. Berge et al. 2006, Findlay et al. 2009, Gooding et al. 2009, Comeau et al. 2010, Byrne 2011, Kroeker et al. 2013, Duarte et al. 2014). These discrepancies have led to generalizations that temperature may have a stronger effect on the overall survival of invertebrates (Findlay et al. 2009, Lischka et al. 2011), while OA will have its greatest influence primarily on calcification and growth rates (Byrne \& Przeslawski 2013). In our study, temperature increase and OA operated synergistically only on growth rates of A. purpuratus, estimated through changes in shell length and height, a result which is in agreement with previous evidence for synergistic effects of temperature and acidification on mollusks (Rodolfo-Metalpa et al. 2011). Thus, our study suggests that changes in shell growth can result from increased dissolution at low $\mathrm{pH}$ and temperature conditions and from increased calcification rates at warmer temperatures, which may actually overcome the negative impact of acidification. However, we also record a moderate but significant reduction in biomass $(-2 \%)$ under low $\mathrm{pH}$, regardless of seawater temperature. This would imply that low $\mathrm{pH}$ was increasing the biological cost of living for the scallops, which could have additional implications for the commercial production of $A$. purpuratus under the influence of upwelling waters (e.g. Talmage \& Gobler 2010, Barton et al. 2012).

The increased calcification rates of A. purpuratus observed at warmer temperatures appeared to be occurring at the expense of reducing the shell thickness, weight, and live biomass. For instance, at the end of the experiment, the mean shell length was positively correlated with mean dry weight (Pearson's $\mathrm{r}=0.99 ; \mathrm{p}=0.003, \mathrm{n}=4$ ). That is, across treatments, larger shells imply heavier shells. However, calcification rate was negatively associated with shell thickness (Pearson's $\mathrm{r}=-0.97 ; \mathrm{p}=0.033, \mathrm{n}=4$ ), which 
suggests that those shell size/weight increments promoted by increased temperature at both $\mathrm{pH}$ conditions could occur at the cost of reducing shell thickness. This potential trade-off highlights some strategies that may be implemented by this cultured species to cope with variability in both climate stressors. In particular, our study suggests that scallops may increase their calcification rate and reach larger shell size during warmer periods (e.g. ENSO) but would be thinner and frailer, and thus more vulnerable to predators and parasites (e.g. perforating polychaetes), as well as increasing the risks of shell breakage and mortality during the manipulation and mechanical sorting symptomatic of the commercial thinning process. In addition, under projected global acidification scenarios (which are already occurring in our study area due to upwelling events, see below and Fig. 7), the observed reduction in growth rates would suggest that it will take longer for scallops to reach marketable size and will require a modification to the timing of the thinning process performed by the aquaculture industry. Future studies should examine strategies that facilitate the survival of scallops when subjected to the thinning and sorting process.

Coastal upwelling modulates the physical and chemical properties of seawater over large areas of the coastal ocean. In relation to the current study, the Pt. Lengua de Vaca upwelling increases $\mathrm{CO}_{2}$-fluxes $\left(f \mathrm{CO}_{2} \sim 1000 \mu \mathrm{atm}\right)$ and promotes strong reductions in $\mathrm{pH}$ ( $\mathrm{pH} \sim 7.6$ ) in Tongoy Bay and the surrounding area (Torres \& Ampuero 2009). These $\mathrm{pH}$ values have previously been proposed as a threshold for negative effects of $\mathrm{OA}$ on shell growth in bivalves (e.g. Berge et al. 2006, Bressan et al. 2014). Thus, the significant net shell dissolution and reduced growth rates of $A$. purpuratus registered at acidified $(\mathrm{pH}$ $\sim 7.7)$ and current temperature $\left(14^{\circ} \mathrm{C}\right)$ conditions suggest that the shell characteristics of the farmed scallops in Tongoy Bay are already compromised during upwelling periods. More generally, it has been suggested that changes in ocean chemistry, which have been driven by rising anthropogenic $\mathrm{CO}_{2}$ emissions, may be inhibiting the development and survival of larval shellfish, and are probably contributing to a global decline in bivalve populations of particular scallop species (Talmage \& Gobler 2010). Some upwelling areas of the Humboldt Current system are showing cooling trends (Gutierrez et al. 2011), which may represent an additional stressor due to the increased kinetic dissolution of carbonate at lower temperatures (Morse et al. 2007). Thus, further environmental monitoring is required to better understand the extent, timing, and persistence of upwelling on the physical-chemical properties of the waters masses circulating inside Tongoy Bay, and their role in reducing shell growth and biomass production of $A$. purpuratus farming operations.

Initial physical-chemical monitoring and water sampling related to the scallop aquaculture was started during 2014. This monitoring has already indicated that during the austral spring (December), the seawater inside Tongoy Bay had $\mathrm{pH}$ values between 7.9 and 8.3, and temperatures between 14 and $16^{\circ} \mathrm{C}$. This variability compares well with the present-day experimental scenario used in the current study (Fig. 7). This implies that, in absence of upwelling influences, Tongoy Bay provides suitable conditions to support scallops with appropriate shell thickness, shell weight, and live tissue biomass as required by scallop aquaculture. In addition, previous studies in the area have suggested the role of upwelling influences in providing an adequate food supply into Tongoy Bay (Gonzalez et al. 1999). However, Tongoy Bay also showed low levels of oxygenation at $10 \mathrm{~m}$ depth (Fig. 6B), which adds a third climatic stressor associated with upwelling ecosystems (e.g. Gruber 2011). Occasional occurrences of hypoxic conditions may also affect the development of A. purpuratus and decrease their physiological capacity to withstand other stressors often encountered by cultured scallops (Brokordt et al. 2013). The mortality data gathered at Invertec-Ostimar farms suggest that, under current temperatures, drops in oxygen concentration below $2 \mathrm{mg} \mathrm{l}^{-1}$ (i.e. hypoxia events, Díaz \& Rosenberg 2008) may be related to the increased mortality of $A$. purpuratus juveniles $(7-15 \mathrm{~mm})$ in September and October, while the mortality of the adult fraction $(>45 \mathrm{~mm}$ ) remains almost stable from July to October. However, hypoxic events are more common from November to January and correspond with an important reduction in mortality of juveniles. This suggests that, compared to the adult fraction, juveniles are more resilient to sources of mortality potentially induced by the underlying environmental variability occurring during the Nov-Jan monitoring period inside Tongoy Bay. Ramajo et al. (2016) recently reported that juvenile $A$. purpuratus are tolerant to OA conditions and showed increased metabolism, shell growth, net calcification, and ingestion rates under OA conditions ( $\mathrm{pH} \sim 7.6$ ). However, as in our study, these positive responses to OA also occurred at increased temperatures (i.e. at $18^{\circ} \mathrm{C}$ ). These observations reflect the occurrence of multiple stressors that may interfere with temperature and acidification 
upwelling-influenced areas with potential impacts on growth and production of the native scallop. Overall, the results of the current study indicate that a review of existing data for scallop production and environmental variability in the area would be valuable, as would be additional experimentation using a multiple-stressor approach.

Acknowledgements. We thank Pedro Alcayaga at InvertecOstimar Hatchery facilities, Jorge López, Sebastian Osores, and Paulina Contreras for their valuable assistance during the experiments and fieldwork. This study was supported by the Millennium Nucleus Center for the Study of Multipledrivers on Marine Socio-Ecological Systems (MUSELS) funded by MINECON NC120086 and FONDECYT grant nos. 1140938 and 1140092 to N.A.L. and M.A.L. C.A.V. was also supported by MINECON IC120019 and Red 14 Doctoral REDOC.CTA, MINEDUC project UCO1202 at the Universidad de Concepción.

\section{LITERATURE CITED}

Aravena G, Broitman B, Stenseth NC (2014) Twelve years of change in coastal upwelling along the central-northern coast of Chile: spatially heterogeneous responses to climatic variability. PLoS ONE 9:e90276

Barton A, Hales B, Waldbusser GG, Langdon C, Feely RA (2012) The Pacific oyster, Crassostrea gigas, shows negative correlation to naturally elevated carbon dioxide levels: implications for near-term ocean acidification effects. Limnol Oceanogr 57:698-710

Beniash E, Ivanina A, Lieb NS, Kurochkin I, Sokolova IM (2010) Elevated level of carbon dioxide affects metabolism and shell formation in oysters Crassostrea virginica. Mar Ecol Prog Ser 419:95-108

Berge JA, Bjerkeng B, Pettersen O, Schaanning MT, Øxnevad S (2006) Effects of increased sea water concentrations of $\mathrm{CO}_{2}$ on growth of the bivalve Mytilus edulis L. Chemosphere 62:681-687

Bibby R, Cleall-Harding P, Rundle S, Widdicombe S, Spicer $\mathrm{J}$ (2007) Ocean acidification disrupts induced defences in the intertidal gastropod Littorina littorea. Biol Lett 3: 699-701

Branch TA, Dejoseph BM, Ray LJ, Wagner CA (2013) Impacts of ocean acidification on marine seafood. Trends Ecol Evol 28:178-186

Bressan M, Chinellato A, Munari M, Matozzo V and others (2014) Does seawater acidification affect survival, growth and shell integrity in bivalve juveniles? Mar Environ Res 99:136-148

Brokordt K, Pérez H, Campos F (2013) Environmental hypoxia reduces the escape response capacity of juvenile and adult scallops Argopecten purpuratus. J Shellfish Res 32:369-376

Buschbaum C, Buschbaum G, Schrey I, Thieltges DW (2007) Shell-boring polychaetes affect gastropod shell strength and crab predation. Mar Ecol Prog Ser 329:123-130

Byrne M (2011) Impact of ocean warming and ocean acidification on marine invertebrate life history stages: vulnerabilities and potential for persistence in a changing ocean. Oceanogr Mar Biol 49:1-42

Byrne M (2012) Global change ecotoxicology: identification of early life history bottlenecks in marine invertebrates, variable species responses and variable experimental approaches. Mar Environ Res 76:3-15

Byrne M, Przeslawski R (2013) Multistressor impacts of warming and acidification of the ocean on marine invertebrates' life histories. Integr Comp Biol 53:582-596

> Caldeira K, Wickett ME (2003) Oceanography: anthropogenic carbon and ocean $\mathrm{pH}$. Nature 425:365

> Chan VBS, Thiyagarajan V, Lu XW, Zhang T, Shih K (2013) Temperature dependent effects of elevated $\mathrm{CO}_{2}$ on shell composition and mechanical properties of Hydroides elegans: insights from a multiple stressor experiment. PLoS ONE 8:e78945

> Comeau S, Gorsky G, Alliouane S, Gattuso JP (2010) Larvae of the pteropod Cavolinia inflexa exposed to aragonite undersaturation are viable but shell-less. Mar Biol 157: 2341-2345

Cubillo AM, Peteiro LG, Fernández-Reiriz MJ, Labarta U (2012) Influence of stocking density on growth of mussels (Mytilus galloprovincialis) in suspended culture. Aquaculture 342-343:103-111

> Díaz RJ, Rosenberg R (2008) Spreading dead zones and consequences for marine ecosystems. Science 321: 926-929

Dickson AG (1990) Standard potential of the reaction $\mathrm{AgCl}(\mathrm{s})+1 / 2 \quad \mathrm{H}_{2}(\mathrm{~g})=\mathrm{Ag}(\mathrm{s})+\mathrm{HCl}(\mathrm{aq})$ and the standard acidity constant of the ion $\mathrm{HSO}_{4}{ }^{-}$in synthetic sea water from 273.15 to $318.15 \mathrm{~K}$. J Chem Thermodyn 22:113-127

> Dickson AG, Millero FJ (1987) A comparison of the equilibrium constants for the dissociation of carbonic acid in seawater media. Deep-Sea Res Part A 34:1733-1743

Dickson AG, Sabine CL, Christian JR (eds) (2007) Guide to best practices for ocean $\mathrm{CO}_{2}$ measurements. PICES Special Publication 3, North Pacific Marine Sciences Organization, Sidney

DOE (US Department of Energy) (1994) Handbook of methods for the analysis of the various parameters of the carbon dioxide system in seawater; version 2.1 . http://cdiac.ornl.gov/oceans/DOE_94.pdf (accessed 29 August 2013)

> Doney SC, Fabry VJ, Feely RA, Kleypas JA (2009) Ocean acidification: the other $\mathrm{CO}_{2}$ problem. Ann Rev Mar Sci 1: 169-192

Duarte C, Navarro JM, Acuña K, Torres R and others (2014) Combined effects of temperature and ocean acidification on the juvenile individuals of the mussel Mytilus chilensis. J Sea Res 85:308-314

> Duarte C, Navarro J, Acuña K, Torres R and others (2015) Intraspecific variability in the response of the edible mussel Mytilus chilensis (Hupe) to ocean acidification. Estuar Coast 38:590-598

Ekstrom JA, Suatoni L, Cooley SR, Pendleton LH and others (2015) Vulnerability and adaptation of US shellfisheries to ocean acidification. Nat Clim Change 5:207-214

> Fabry VJ, Seibel BA, Feely RA, Orr JC (2008) Impacts of ocean acidification on marine fauna and ecosystem processes. ICES J Mar Sci 65:414-432

Feely RA, Sabine CL, Hernandez-Ayon JM, Ianson D, Hales B (2008) Evidence for upwelling of corrosive 'acidified' water onto the continental shelf. Science 320:1490-1492

> Filgueira R, Comeau LA, Landry T, Grant J, Guyondet T, Mallet A (2013) Bivalve condition index as an indicator of aquaculture intensity: a meta-analysis. Ecol Indic 25: 215-229

Findlay HS, Wood HL, Kendall MA, Spicer JI, Twitchett RJ, 
Widdicombe S (2009) Calcification, a physiological process to be considered in the context of the whole organism. Biogeosci Discuss 6:2267-2284

Fitzer SC, Cusack M, Phoenix VR, Kamenos NA (2014) Ocean acidification reduces the crystallographic control in juvenile mussel shells. J Struct Biol 188:39-45

Fréchette M, Lachance-Bernard M, Daigle D (2010) Body size, population density and factors regulating suspension-cultured blue mussel (Mytilus spp.) populations. Aquat Living Resour 23:247-254

Gattuso JP, Magnan A, Billé R, Cheung WWL and others (2015) Contrasting futures for ocean and society from different anthropogenic $\mathrm{CO}_{2}$ emissions scenarios. Science 349:aac4722, doi:10.1126/science.aac4722

Gazeau F, Parker LM, Comeau S, Gattuso JP and others (2013) Impacts of ocean acidification on marine shelled mollusks. Mar Biol 160:2207-2245

> Gazeau F, Urbini L, Cox TE, Alliouane S, Gattuso JP (2015) Comparison of the alkalinity and calcium anomaly techniques to estimate rates of net calcification. Mar Ecol Prog Ser 527:1-12

González L, López A, Pérez C, Riquelme A and others (1999) Growth of the scallop, Argopecten purpuratus, in southern Chile (Lamarck, 1819). Aquaculture 175:307-316

Gooding RA, Harley CDG, Tang E (2009) Elevated water temperature and carbon dioxide concentration increase the growth of a keystone echinoderm. Proc Natl Acad Sci USA 106:9316-9321

Grefsrud SE, Strand $\varnothing$ (2006) Comparison of shell strength in wild and cultured scallops (Pecten maximus). Aquaculture 251:306-313

Gruber N (2011) Warming up, turning sour, losing breath: ocean biogeochemistry under global change. Philos Trans A Math Phys Eng Sci 369:1980-1996

Gruber N, Hauri C, Lachkar Z, Loher D, Fröhlicher TL, Plattner GK (2012) Rapid progression of ocean acidification in the California Current System. Science 337: $220-223$

Gutiérrez D, Bouloubassi I, Sifeddine A, Purca S and others (2011) Coastal cooling and increased productivity in the main upwelling zone off Peru since the mid-twentieth century. Geophys Res Lett 38:L07603, doi:10.1029/2010 GL046324

Harley CDG, Hughes AR, Hultgren KM (2006) The impacts of climate change in coastal marine systems. Ecol Lett 9: 228-241

> Helmuth B, Mieszkowska N, Moore P, Hawkins S (2006) Living on the edge of two changing worlds: forecasting the responses of rocky intertidal ecosystems to climate change. Annu Rev Ecol Evol Syst 37:373-404

> Hennen DR, Hart DR (2012) Shell height to weight relationships for Atlantic sea scallops (Placopecten magellanicus) in offshore U.S. waters. J Shellfish Res 31:1133-1144

Hiebenthal C, Philipp EER, Eisenhauer A, Wahl M (2013) Effects of seawater $p \mathrm{CO}_{2}$ and temperature on shell growth, shell stability, condition and cellular stress of Western Baltic Sea Mytilus edulis (L.) and Arctica islandica (L.). Mar Biol 160:2073-2087

IPCC (Intergovernmental Panel on Climate Change) (2014) Climate change 2014: impacts, adaptation, and vulnerability. Contribution of Working Group II to the 5th Assessment Report of the Intergovernmental Panel on Climate Change. Cambridge University Press, Cambridge

Jory DE, Iversen ES (1988) Shell strength of queen conch,
Strombus gigas L: aquaculture implications. Aquacult Fish Manag 19:45-51

Ko GW, Dineshram R, Campanati C, Chan VB, Havenhand J, Thiyagarajan V (2014) Interactive effects of ocean acidification, elevated temperature, and reduced salinity on early-life stages of the Pacific oyster. Environ Sci Technol 48:10079-10088

Kroeker KJ, Kordas R, Crim R, Hendriks I and others (2013) Impacts of ocean acidification on marine organisms: quantifying sensitivities and interaction with warming. Glob Change Biol 19:1884-1896

Lafrance M, Cliche G, Haugum GA, Guderley H (2003) Comparison of cultured and wild sea scallops Placopecten magellanicus, using behavioural responses and morphometric and biochemical indices. Mar Ecol Prog Ser 250:183-195

> Lischka S, Büdenbender J, Boxhammer T, Riebesell U (2011) Impact of ocean acidification and elevated temperatures on early juveniles of the polar shelled pteropod Limacina helicina: mortality, shell degradation, and shell growth. Biogeosciences 8:919-932

> Mackenzie CL, Ormondroyd GA, Curling SF, Ball RJ, Whitely NM, Malham SK (2014) Ocean warming, more than acidification, reduces shell strength in a commercial shellfish species during food limitation. PLoS ONE 9: e86764

Maguire J, Fleury P, Burnell G (1999) Some methods for quantifying quality in scallops Pecten maximus (L.). J Shellfish Res 18:59-66

McClintock JB, Angus RA, McDonald MR, Amsler CD, Catledge SA, Vohra YK (2009) Rapid dissolution of shells of weakly calcified Antarctic benthic macroorganisms indicates high vulnerability to ocean acidification. Antarct Sci 21:449-456

Mehrbach C, Culberson CH, Hawley JE, Pytkowicz RN (1973) Measurement of the apparent dissociation constants of carbonic acid in seawater at atmospheric pressure. Limnol Oceanogr 18:897-907

Meinshausen M, Smith SJ, Calvin K, Daniel JS and others (2011) The RPC greenhouse gas concentrations and their extensions from 1765 to 2300. Clim Change 109:213-241

Melzner F, Stange P, Trübenbach K, Thomsen J and others (2011) Food supply and seawater $p \mathrm{CO}_{2}$ impact calcification and internal shell dissolution in the blue mussel Mytilus edulis. PLoS ONE 6:e24223

> Morse JW, Arvidson RS, Luttge A (2007) Calcium carbonate formation and dissolution. Chem Rev 107:342-381

- Navarro JM, Torres R, Acuña K, Duarte C and others (2013) Impact of medium-term exposure to elevated $\mathrm{pCO}_{2}$ levels on the physiological energetics of the mussel Mytilus chilensis. Chemosphere 90:1242-1248

Nienhuis S, Palmer R, Harley C (2010) Elevated $\mathrm{CO}_{2}$ affects shell dissolution rate but not calcification rate in a marine snail. Proc R Soc Lond B Biol Sci 277:2553-2558

> Orr JC, Fabry VJ, Aumont O, Bopp L and others (2005) Anthropogenic ocean acidification over the twenty-first century and its impact on calcifying organisms. Nature 437:681-686

Palmer AR (1982) Growth in marine gastropods: a nondestructive technique for independently measuring shell and body weight. Malacologia 23:63-73

Pennington BJ, Currey JD (1984) A mathematical model for the mechanical properties of scallop shells. J Zool 202: 239-263

Pierrot D, Lewis E, Wallace DWR (2006) MS Excel program 
developed for $\mathrm{CO}_{2}$ system calculations, ORNL/CDIAC105. Carbon Dioxide Information Analysis Center, Oak Ridge National Laboratory, US Department of Energy, Oak Ridge, TN

Ramajo L, Marbà N, Prado L, Peron S and others (2016) Biomineralization changes with food supply confer juvenile scallops (Argopecten purpuratus) resistance to ocean acidification. Glob Change Biol 22:2025-2037

Ries JB, Cohen AL, McCorkle DC (2009) Marine calcifiers exhibit mixed responses to $\mathrm{CO}_{2}$-induced ocean acidification. Geology 37:1131-1134

Rodolfo-Metalpa R, Houlbreque F, Tambutte E and others (2011) Coral and mollusc resistance to ocean acidification adversely affected by warming. Nat Clim Change 1: 308-312

SERNAPESCA (Servicio Nacional de Pesca y Acuicultura) (2014) Anuarios estadísticos del Servicio Nacional de Pesca y Acuicultura. www.sernapesca.cl

Sokal RR, Rohlf FJ (1995) Biometry: the principles and practice of statistics in biological research. WH Freeman, New York, NY

Stotz WB (2000) When aquaculture restores and replaces a overfished stock, is the conservation of the species assured? The case of the scallop Argopecten purpuratus (Lamarck, 1819) in northern Chile. Aquacult Int 8:237-247

Sydeman WJ, García-Reyes M, Schoeman DS, Rykaczewski RR, Thompson SA, Black BA, Bograd SA (2014) Climate change and wind intensification in coastal upwelling ecosystems. Science 345:77-80

Talmage S, Gobler C (2009) The effects of elevated carbon dioxide concentrations on the metamorphosis, size, and survival of larval hard clams (Mercenaria mercenaria), bay scallops (Argopecten irradians), and eastern oysters (Crassostrea virginica). Limnol Oceanogr 54:2072-2080

Talmage SC, Gobler C (2010) Effects of past, present, and future ocean carbon dioxide concentrations on the growth and survival of larval shellfish. Proc Natl Acad Sci USA 107:17246-17251

Thiel M, Macaya EC, Acuña E, Arntz WE and others (2007) The Humboldt Current system of northern and central Chile. Oceanographic processes, ecological interactions and socioeconomic feedback. Oceanogr Mar Biol Annu Rev 45:195-344

Editorial responsibility: Symon Dworjanyn, Coffs Harbour, New South Wales, Australia
Thomsen J, Gutowska MA, Saphörster J, Heinemann A and others (2010) Calcifying invertebrates succeed in a naturally $\mathrm{CO}_{2}$-rich coastal habitat but are threatened by high levels of future acidification. Biogeosciences 7:3879-3891

Thomsen J, Casties I, Pansch C, Körtzinger A, Melzner F (2013) Food availability outweighs ocean acidification effects in juvenile Mytilus edulis: laboratory and field experiments. Glob Chang Biol 19:1017-1027

Torres R, Ampuero P (2009) Strong $\mathrm{CO}_{2}$ outgassing from high nutrient low chlorophyll coastal waters off central Chile $\left(30^{\circ} \mathrm{S}\right)$ : the role of dissolved iron. Estuar Coast Shelf Sci 83:126-132

Torres R, Manriquez PH, Duarte C, Navarro JM, Lagos NA, Vargas CA, Lardies MA (2013) Evaluation of a semiautomatic system for long-term seawater carbonate chemistry manipulation. Rev Chil Hist Nat 86:443-451

Tunnicliffe V, Davies KT, Butterfield DA, Embley RW, Rose JM, Chadwick Jr WW (2009) Survival of mussels in extremely acidic waters on a submarine volcano. Nat Geosci 2:344-348

Underwood AJ (1997) Experiments in ecology: their logical design and interpretation using analysis of variance. Cambridge University Press, Cambridge

Waldbusser GG, Brunner EL, Haley BA, Hales B, Langdon CJ, Prahl FG (2013) A developmental and energetic basis linking larval oyster shell formation to acidification sensitivity. Geophys Res Lett 40:2171-2176

> Watson SA, Peck LS, Tyler PA, Southgate PC, Tan KS, Day RW, Morley SA (2012) Marine invertebrate skeleton size varies with latitude, temperature and carbonate saturation: implications for global change and ocean acidification. Glob Change Biol 18:3026-3038

Welladsen HM, Southgate PC, Heimann K (2010) The effects of exposure to near-future levels of ocean acidification on shell characteristics of Pinctada fucata (Bivalvia: Pteriidae). Molluscan Res 30:125-130

White MM, McCorkle DC, Mullineaux LS, Cohen AL (2013) Early exposure of bay scallops (Argopecten irradians) to high $\mathrm{CO}_{2}$ causes a decrease in larval shell growth. PLoS ONE 8:e61065

- Wood HL, Spicer JI, Widdicombe S (2008) Ocean acidification may increase calcification rates, but at a cost. Proc R Soc Lond B Biol Sci 275:1767-1773

Submitted: October 12, 2015; Accepted: April 19, 2016

Proofs received from author(s): May 14, 2016 